\title{
EFEKTIFTTAS KONSELING PEMULIHAN BAGI TENAGA PENDIDIK
}

\author{
Oleh : Rifky Serva TuJu, S.Th., M.Pd \\ Dosen
}

\begin{abstract}
ABSTRAK
Penulisan karya tulis ini bertujuan untuk memaparkan efektifitas konseling pemulihan bagi tenaga pendidik dalam proses pelaksanaan konseling di sekolah atau perguruan tinggi yang membutuhkan konseling sebagai alat untuk menolong siswa yang sedang memiliki masalah. Tulisan ini termasuk jenis tulisan yang mengembangkan pola bimbingan pribadi yang berfokus pada pemulihan siswa, dalam proses bimbingan firman Tuhan sebagai bahan yang digunakan untuk membimbing siswa. Proses bimbingan juga memiliki tujuan agar siswa dapat dipulihkan oleh Tuhan secara pribadi. Koseling pemulihan setidaknya dapat menjadi rujukan bagi tenaga pendidik untuk dapat menolong dan membimbing siswa-siswi yang sedang dalam masalah di sekolah. Konseling Kristen yang efektif adalah konseling yang berusaha menolong, membimbing dan mengatasi konseli yang bermasalah. Dalam arti bahwa konselor dapat menolong klien dalam menyelesaikan problematika pribadinya.
\end{abstract}

\section{Kata Kunci : Efektifitas, Konseling, Pemulihan}




\section{A. KONSELING PEMULIHAN}

Pada bagian ini penulis akan memaparkan mengenai Pengertian konseling pemulihan, dan dalam tujuan konseling ada beberapa penjelasan mengenai adanya keterbukaan, membuka jalur komunikasi dengan Allah, membuka komunikasi dengan diri sendiri, membuka komunikasi dengan orang lain, membawa pemulihan pada konseli.

\section{B. DEFINISI KONSELING PEMULIHAN}

Seorang konselor haruslah sepenuhnya memberikan hidup untuk membantu orang-orang yang membutuhkan bimbingan konseling. Dan sebagai konselor harus dapat memberikan bantuan kepada konseli. Dalam bagian ini penulis akan membahas mengenai konseling pemulihan. Konseling Kristen yang efektif adalah konseling yang berusaha menolong, membimbing dan mengatasi konseli yang bermasalah. Dalam arti bahwa konselor dapat menolong klien dalam menyelesaikan problematika pribadinya. Ketika dalam proses pembimbingan konselor Kristen berusaha mengaplikasikan kebenaran firman Tuhan atas persoalan-persoalan hidupnya. ${ }^{1}$ Dalam konseling Kristen selain konselor sebagai pembimbing, konselor juga dapat menolong klien agar mendapatkan pemulihan. Pengertian konseling Pemulihan dapat diartikan sebagai berikut.

Di Alkitab terdapat 8 ayat yang menggunakan kata "pemulihan," atau "dipulihkan," (Im. 26:34; Ams. 6:15, Ams. 29:1; Yeh. 16:55; Dan. 8:14, Dan. 9:25; 2 Taw. 36:16; Kis. 3:21), dan semua ayat tersebut berko-notasi kepada pemulihan terhadap kondisi kehidupan manusia termasuk pemulihan terhadap hal-hal materi seperti keadaan kota atau alam. Sebetulnya pemulihan adalah proses normal dan wajar dalam sebuah peristiwa atau dalam sebuah proses yang panjang hingga pemulihan itu selesai terjadi. Jika dikaitkan dengan kehidupan rohani orang Kristen, maka pemulihan dapat diartikan sebagai proses yang terjadi sebagai suatu peristiwa tunggal sumur hidup, yang kita kenal sebagai proses bertumbuh secara terus menerus, atau yang dapat kita sebut sebagai "progressive sanctification," yang finalitasnya terjadi

${ }^{1}$ Gary R. Collins, Konseling Kristen Yang Efektif (Malang: Literatur SAAT, 2012), hlm. 13. 
pada kedatangan Kristus yang kedua kali (Rm. 8:30). Selain itu kalau kita pelajari di dalam Perjanjian Lama atau di Perjanjian Baru, maka pemulihan dapat diartikan sebagai bagian dari proses "progressive sanctification," atau proses jatuh bangun yang dialami orang Kristen, dan dalam proses itu Allah selalu menghendaki pemulihan atau pertobatan dalam hidup orang Kristen. ${ }^{2}$

Untuk memahami betapa pentingnya pelayanan konseling pemulihan perlu diperhatikan terlebih dahulu kesaksian Alkitab. Sesuai dengan kesaksian Alkitab, baik Perjanjian Lama maupun Perjanjian Baru terlihat bahwa pendampingan (konseling) itu bersumber dari Allah sendiri. Di dalam Kejadian 3, misi pendampingan itu dilakukan oleh Allah sendiri. Allah hadir di saat Adam (manusia) berada dalam keterasingan, kesepian, ketakutan dan kecemasan serta perasaan malu karena perbuatannya. Allah hadir dalam suatu relasi khusus untuk mendampingi, menopang dan membimbingnya, sehingga ia dapat hidup secara bertanggung jawab atas segala perbuatannya. Dalam pendampingan itu Allah mendamaikan dan memulihkan hubungannya yang telah terputus dengan Allah maupun dengan lingkungannya, sehingga relasi itu dapat tercipta kembali secara baru yang penuh makna. Dalam pendampingan itu juga Allah mengadakan atau mengikat Perjanjian dengan Adam (Kej. 3:15), dan selanjutnya Allah dan manusia itu bertemu dan saling berhubungan dalam ikatan relasi Perjanjian. $^{3}$

Artinya pemulihan yang terjadi dalam diri orang Kristen juga seharusnya tidak dapat dilihat sebagai bagian yang terpisah dari keberadaannya yang utuh. Banyak orang menggunakan istilah "pemulihan jiwa" karena menganggap jiwa itu sebagai pusat dari keberadaan dan hidup seseorang, namun ternyata manusia tidak hanya terdiri dari jiwa saja. Jadi, dasar dari seluruh kehidupan Kristen adalah pemahaman yang benar tentang pembenaran. Titik akhir kedewasaan adalah: Pemuliaan terakhir (glorification). ${ }^{4}$ Dalam segala aspek keberadaannya orang Kristen harus bertumbuh secara seimbang, baik dalam aspek pikiran, perasaan dan tindakannya. Dengan demikian

${ }^{2}$ Diambil 5 November 2016.http://reformata.com/news/view/5390/pemulihanjiwa.

${ }^{3}$ Tjaard G. Hommes dan E. Gerrit Singgih, Teologi Dan Praksis Pastoral. Antoloi Teologi Pastoral (Yogyakarta: Kanisius, 1992), hlm. 409.

${ }^{4}$ Diambil 3 November 2016. Konseling Yang Efektif \& Alkitabiah: Sebuah Acuan Untuk Membantu Anda Menjadi Konselor Yang Handa, PDF, hlm. 2. 
dapat disimpulkan bahwa istilah pemulihan sesungguhnya adalah sebuah istilah lain dari proses pertumbuhan atau proses perubahan yang sedang dan harus dialami oleh semua orang Kristen di dunia ini.

\section{TUJUAN KONSELING PEMULIHAN}

Dalam bagian ini penulis akan memaparkan mengenai, adanya keterbukaan, membuka jalur komunikasi dengan Allah, membuka komunikasi dengan diri sendiri, membuka komunikasi dengan orang lain, membawa pemulihan pada konseli.

\section{Adanya Keterbukaan}

Konseling Kristen bertujuan untuk membina komunikasi kearah keterbukaan, yang menyiapkan jalan bagi penyembuhan yang dikerjakan oleh Allah. ${ }^{5}$ Sutirna mengatakan seorang konselor selalu mempunyai tujuan dalam membimbing seseorang, dan yang paling dikehendaki oleh seorang konselor terhadap klien itu adalah keterbukaan dan tidak berpura-pura ketika dalam proses konseling berlangsung. ${ }^{6}$

Kesulitan paling berat yang dialami olleh seorang konselor adalah ketika klien tidak memiliki sifat keterbukaan. Sikap tidak terbuka membuat suatu masalah dalam konseling sangat sulit dipecahkan. Ada begitu banyak orang yang di konseling ketika diperhadapkan dalam bagian keterbukaan masalah sangat sulit berkata jujur dan terbuka sehingga menyulitkan konselor. Biasanya dalam pelaksanaan konseling sangat diperlukan sebuah keterbukaan dan berterus terang. Keterbukaan bukan hanya dilakukan oleh klien tetapi juga konselor itu sendiri.

Prayitno dan Erman Amti mengatakan keterusterangan dan kejujuran akan dilakukan oleh klien jika klien telah betul-betul percaya kepada konselor dan benar-benar mengharapkan bantuan dari konselor.

\footnotetext{
${ }^{5}$ Magdalena Tomatala, Konselor Kompeten Pengantar Konseling Terapi Untuk Pemulihan (Jakarta: YT Leadership Foundation, 2000), hlm. 21.

${ }^{6} \mathrm{H}$. Sutirna, Bimbingan Dan Konseling Pendidikan Forma Nonformal Dan Informal (Yogyakarta: Andi Offset, 2013), hlm. 27.
} 
Keterbukaan akan semakin berkembang apabila klien tahu bahwa konselornyapun terbuka. ${ }^{7}$

Asas keterbukaan adalah asas yang menghendaki agar klien yang menjadi sasaran layanan/kegiatan bersikap terbuka dan tidak berpurapura, baik dalam memberikan keterangan tentang dirinya sendiri maupun dalam menerima berbagai informasi dan materi dari luar yang berguna bagi pengembangan dirinya. Konselor sebagai pembimbing berkewajiban mengembangkan keterbukaan seorang klien. ${ }^{8}$

Keterbukaan dalam hal ini harus dilakukan dari dua arah, yaitu konselor sebagai pembimbing dan juga klien yang dibimbing. Sebab klien tidak dapat terbuka jika dia mengetahui bahwa konselor juga tidak memiliki keterbukaan dalam membimbingnya. Dalam hal ini konselor harus menjawab semua pertanyaan-pertanyaan yang ditanyakan oleh klien dengan jujur, begitu juga sebaliknya. Klien harun menjawab semua pertanyaan yang ditanyakan oleh konselor dengan sejujur-jujurnya sehingga mendapatkan hasil konseling yang maksimal dan jalan keluar yang tepat. karena adanya keterbukaan.

\section{Membuka Jalur Komunikasi Dengan Allah}

Dalam hal ini konseling Kristen bertujuan membuka jalur komunikasi yang baik dengan Tuhan, yang bermuara kepada penyembuhan hubungan dan luka batin yang terpendam di dalam diri konseli. ${ }^{9}$ Berkomunikasi dengan Tuhan adalah hal yang paling penting dalam diri seorang klien. Hal ini memiliki sasaran yang tepat dan dapat mengesampingkan suatu komunikasi yang tidak memenuhi sasaran. Juga dapat memberikan tanggapan secara Alkitabiah, untuk mendahulukan Tuhan, berusaha bertingkah laku seperti yang Tuhan kehendaki. Sebab komunikasi dengan Tuhan akan memberikan suatu kebenaran yang luar biasa ialah ketika konselor bersama klien

${ }^{7}$ H. Prayitno dan Erman Emti, Dasar-dasar Bimbingan Dan Konseling (Jakarta: Rhineka Cipta, 2013), hlm. 116.

${ }^{8}$ Diambil 7 Novemberhttp://tholearies.blogspot.co.id/2014/02/bimbingankonseling-pengertian-tujuan.html.

${ }^{9}$ Tomatala, Konselor Kompeten Pengantar Konseling Terapi Untuk Pemulihan, hlm. 21. 
mengarahkan semua kekuatan tugas seperti yang diinginkan Yesus Kristus. ${ }^{10}$

Sangatlah menolong, bila klien dapat mengungkapkan perasaannya kepada Tuhan, bahkan berani menangis ketika berkomunikasi dengan Tuhan. Colins mengutip apa yang dikatakan oleh Paulus dalam Alkitab: Ingatlah bahwa Tuhan ada di dekat kita, dan nyatakanlah segala keinginanmu kepada Allah dalam doa dan permohonan. ${ }^{11}$ Kebanyakan konselor menyadari bahwa dirinya mampu menolong klien dan begitu juga dengan klien, menganggap bahwa dirinya mampu memakai pikirannya untuk dapat menyelesaikan masalahnya yang dihadapi. Terkadang lupa bahwa hanyalah dengan pertolongan Tuhan saja konselor atau konseli dapat mengerti dan menolong. ${ }^{12}$

Setiap melakukan konseling, konselor perlu berkomunikasi dengan Tuhan agar Tuhan dapat menolong, membantu konselor dalam melakukan konseling. Sebab manusia punya banyak kelemahan dan kekurangan, karena itu manusia perlu Tuhan untuk menolong kita dalam konseling orang lain. Allah yang mahatahu harus ada dalam pikiran seorang konselor dalam pelayanan ini. Sehingga komunikasi dengan Allah selalu terjalin dan tanpa komunikasi dengan Allah pelayanan konseling tidak dapat berjalan dengan baik.

\section{Membuka Komunikasi Dengan Diri Sendiri}

Komunikasi merupakan langkah pertama dalam proses konseling, membina hubungan sangatlah peting dan konseling adalah bentuk khusus dari hubungan atau komunikasi personal. Dalam hal ini diartikan bahwa kaidah-kaidah yang berlaku pada proses komunikasi yang berarti berlaku juga dalam proses konseling.

Komunikasi merupakan sebuah intepretasi dalam diri seseorang. Namun dalam dunia nyata komunikasi dengan diri sendiri tidak jarang dilakukan oleh masing-masing individu. Komunikasi secara pribadi tersebut muncul oleh karena sering terjadi permasalahan dalam diri orang tersebut. Entah itu baik atau buruk. Di sini konseling Kristen

${ }^{10}$ Larry Crabb, Konseling Yang Efektif Dan Alkitabiah (Yogyakarta: Andi Offset, 2005), hlm. 15.

${ }^{11}$ Gary R. Collins, Konseling Kristen Yang Efektif (Malang: Literatur SAAT, 2012), hlm. 59.

${ }^{12}$ Ibid., hlm. 67. 
bertujuan membuka jalur komunikasi dengan diri sendiri, yang bermuara kepada penyembuhan hubungan dan luka batin yang terpendam di dalam diri konseli. ${ }^{13}$

Menurut para ahli psikologi, manusia mempunyai berbagai kebutuhan primer dalam hidup mereka tergantung kematangan pribadi. Kegagalan untuk memenuhi kebutuhan tersebut adalah masalah dalam hidup mereka. ${ }^{14}$ Keunikan lain dari konseling pemulihan adalah orientasinya kepada pribadi (individu atau kelompok) dan bukan orientasi masalah. Hal itu menjadi pusat perhatian dalam konseling pemulihan adalah pribadi konseli, sebab pola kepribadiannya berkaitan erat dengan masalahnya dan mungkin masalah itu sendiri. Apabila kita hanya menyelesaikan masalahnya, tanpa memperhatikan unsur kepribadiannya mungkin sesaat kita dapat menolongnya, tetapi ia akan kurang mampu mengatasi masalah yang akan muncul di kemudian hari. Oleh sebab itu sasaran yang sederhana adalah pertumbuhan dan kedewasaan pribadi konseli. Dengan demikian konseling tidak saja menolong atau memecahkan masalah konseli, tetapi juga membimbing dan menolong mereka yang bermasalah untuk belajar mengatasi persoalannya sendiri secara mandiri.

Jadi, proses konseling akan menjadi stimulus untuk menumbuhkan kedewasaan konseli. Dalam orientasi yang demikian seorang konselor pastoral berusaha mengembangkan sikap penghargaan dan penerimaan terhadap sesama yang bermasalah tanpa syarat, ${ }^{15}$ menanamkan rasa tanggung jawab dan kesanggupan pada pribadi yang bermasalah. Oleh karena pribadi yang akan mengambil keputusan dan melaksanakannya adalah pribadi yang bermasalah, maka konseling pastoral berusaha untuk membangkitkan kesanggupan individu untuk memutuskan dan mengambil tanggung jawab atas setiap persoalan yang dihadapinya. ${ }^{16}$ Pendekatan yang demikian, adalah sangat tepat, oleh karena memberdayakan sesama yang bermasalah untuk dapat menolong diri sendiri serta belajar untuk tumbuh menuju ke dewasa.

\footnotetext{
${ }^{13}$ Tomatala, Konselor Kompeten Pengantar Konseling Terapi Untuk Pemulihan, hlm. 21 .

${ }^{14}$ Yakub B. Susabda, Menjadi Konselor Yang Profesional (Yogyakarta: Andi Offset, 2007), hlm. 18.

${ }^{15}$ Gerald Corey, Teori Dan Praktek Konseling Dan Psikoterapi, pen., E. Koeswara (Bandung: PT. Eresco, 1988), hlm. 101.

${ }^{16}$ E. Koeswara, Logoterapi: Psikoterapi Victor Frankl (Yogyakarta: Kanisius, 1992), hlm. 43.
} 


\section{EFEKTIFITAS KONTEKS PEMULIHAN MENURUT 2 SAMUEL 12:1-14}

Di dalam 2 Samuel 11 penulis kitab mengisahkan perbuatan seorang raja yang sangat kejam terhadap rakyatnya. Baik seorang yang tak bermoral, ia meniduri seorang wanita yang sudah bersuami, kemudian dengan jebakan yang busuk ia menyuruh suami wanita yang ia tiduri itu untuk pulang ke rumah supaya ia tidur dengan isterinya dan kejahatannya tidak diketahui orang lain. Namun suami wanita itu, yang tidak lain adalah salah satu prajuritnya yang setia tidak tega menghampiri isterinya sementara rekan-rekannya para prajurit menyabung nyawa di dalam peperangan. Walaupun demikian hati sang raja tidak juga tergugah akan kesetiaan pahlawannya ini, ia memilih untuk membunuhnya di medan peperangan dengan siasat yang licik. Kemudian tewaslah salah satu prajuritnya yang setia itu oleh karena perintahnya. Lalu ia mengambil isteri prajurit tersebut dan menjadikannya isterinya. ${ }^{17}$

Kisah ini merupakan salah satu kisah yang paling tragis di dalam Alkitab. Kisah yang sangat dramatis mengenai seorang yang berkenan di hati Tuhan namun melakukan perbuatan yang sepertinya "tidak terampuni." Namun hal ini adalah sebuah realita yang dicatat oleh Alkitab untuk menjadi pembelajaran. Seorang yang dekat dengan Tuhan melakukan tindakan yang sangat kejam dan menjijikkan. Selama beberapa waktu berjalan, Daud tidak menyadari bahwa ia telah melakukan dosa yang sangat besar. Bahkan tidak ada kepekaan dalam dirinya bahwa dosa dan kesalahannya yang sangat fatal itu membuat Allah sangat murka kepadanya. Apa yang dilakukan Daud adalah jahat di mata Tuhan (2 Sam. 11:27b).

Kisah dari pada kehidupan Daud dijelaskan sangat jelas di dalam Kitab 2 Samuel 11:1-27, bahwa Daud membuat suatu kesalahan yang sangat besar karena mengambil Betsyeba sebagai isterinya dan membunuh Uria. Daud menyuruh Yoab untuk menempatkan Uria di bagian paling depan dalam peperangan sehingga suami dari Betsyeba itu mati dalam pertempuran (2 Sam. 11:14-21). Namun sekalipun Daud sudah melakukan kejahatan di mata Tuhan, Daud seolah-olah tidak merasa bersalah. Seakan-akan Daud tidak peduli dengan kematian

\footnotetext{
${ }^{17}$ http://www.studialkitab.com/2010/03/daud-ditegur-natan-ketidaksadaranakan.html.
} 
daripada Uria dan mengambil Betsyeba sebagai isterinya (II Sam. 11:22-27).

Seorang penafsir bernama D. F. Payne mengatakan apa yang dilakukan oleh Daud pada awalnya tidak berlebihan, tetapi kurang jelas apakah Betsyeba salah atau tidak, mungkin peristiwa awal dari rentetan peristiwa yang mendatangkan malapetaka itu adalah kebetulan saja. Dalam semua bagian Alkitab yang mengemukakan nama Betsyeba, ia tidak disebut selaku pihak yang bersalah. ${ }^{18}$ Namun Philip Johnson membantah apa yang dikatakan oleh Payne diatas, Johnson mengatakan bahwa berbagai tindakan yang dilakukan oleh Daud dan Batsyeba adalah sebuah kekejian ketimbang korban-korban yang berjatuhan dalam peperangan melawan kerajaan Daud. ${ }^{19}$ Homer Heater, JR membenarkan apa yang dikatakan oleh Johnson. Homer mengatakan bahwa:

Dosa Daud dan Batsyeba menggambarkan serangkaian hal yang bertentangan. Daud, abdi Allah, yang dipilih menjadi pemimpin umat-Nya, tidak dapat memenuhi syarat-syarat dari jabatannya. Bukan saja dia tidak dapat membuat pertimbangan dengan benar, tetapi perilakunya sendiri sangat melanggar rasa keadilan. ${ }^{20}$

Ketidakpedulian Daud menunjukkan sifat buruknya. Menunjukkan bahwa dia adalah seorang yang jahat. Magdalena Tomatala mengatakan, "sikap Daud disini terlihat sebagai atau seperti orang yang hatinya telah diselar atau di cap dengan besi panas, atau orang yang telah mengeraskan hati terhadap kesalahan yang telah dibuatnya."21 Sifat buruk Daud yang ada dalam cerita ini menunjukkan bahwa dia tidak lagi taat kepada Tuhan, bahkan 2 Samuel 11:27 katakan bahwa hal yang telah dilakukan Daud adalah jahat di mata Tuhan.

${ }^{18}$ D. F. Payne, Tafsiran Alkitab Masa Kini, pen,. M. Rikin (Jakarta: Yayasan Komunikasi Bina Kasih, 2010), hlm. 1:484.

${ }^{19}$ Philip Johnston, Pengantar Untuk Mengenal Alkitab Memahami Alkitab Berdasarkan Sejarah Tema Dan Penafsiran, pen., Christian Nugroho (Bandung: Yayasan Kalam Hidup, 2011), hlm. 138.

${ }^{20}$ Homer Heater, JR, Teologi Alkitabiah Perjanjian Lama, pen., Suhadi Yeremia (Malang: Gandum Mas, 2015), hlm. 265.

${ }^{21}$ Tomatala, Konselor Kompeten Pengantar Konseling Terapi Untuk Pemulihan, hlm. 28 . 
Peristiwa yang dilakukan oleh Daud adalah jahat di mata Tuhan, dan itu adalah kekejian bagi Allah. Keegoisan dan kejahatan Daud mengakibatkan Uria harus mati dalam suatu perencanaan Daud. Dan semua itu adalah jahat di mata Tuhan. Jika dilihat dalam 2 Samuel 12:1-4 menceritakan bahwa Tuhan mengutus Nabi Natan datang kepada Daud dan menegur dia. Natan memakai sebuah perumpamaan atau analogi, untuk menegur Daud. Mendengar apa yang dikatakan oleh Natan, Daud menjadi marah dan mengatakan bahwa si kaya harus dihukum mati dan anak domba betina itu harus dibayar empat kali lipat. Setelah Daud berkata demikian barulah Natan memberitahukan kepada Daud bahwa dialah orang tersebut. Rothlisberger mengatakan tentulah hal tersebut mengejutkan raja Daud, tiba-tiba Daud sadar bahwa di dalam perkara ini dia bukanlah hakim, melainkan justru si terdakwa, dan hukuman yang akan ia jatuhkan adalah untuk dirinya sendiri. ${ }^{22}$

Lanjut Rothlisberger, frasa "engkaulah orang itu" mengandung beberapa arti: "Engkaulah si kaya yang kikir dan tamak, yang telah memgambil milik dan pokok cinta si miskin; engkaulah dia yang tidak kenal belas kasihan, dan oleh sebab itu hukuman mati berlaku terhadap dirimu sendiri." 23

Keberanian Natan menegur Daud berlanjut. Natan mengatakan mengapakah engkau menghina Tuhan? Dengan melakukan apa yang jahat di mata Tuhan? Uria, orang Het itu, kau biarkan ditewaskan dengan pedang. Sekalipun Daud tidak membunuh Uria secara langsung tetapi Daud yang merencanakan semuanya itu untuk membunuh Uria. Rothlisberger mengatakan kematian Uria itu tidak lain dan tidak bukan adalah pembunuhan oleh Daud saja. ${ }^{24}$

Sebagai seorang kaunselor rohani yang mengharapkan Tuhan dalam tindakannya, harus melihat dan menggunakan pola pemikiran Kristus dan Firman-Nya untuk menangani suatu krisis yang dihadapi oleh seseorang. Banyak sekali catatan dan cerita yang dibahas dalam Alkitab untuk kita telusuri dan mendapatkan kaedah konseling. Antara cerita yang diketengahkan oleh Alkitab adalah cerita mengenai Natan dan Daud (2 Sam. 12: 1-25), di mana Natan yang telah memberikan nasihat kepada Daud sehinggalah Daud menyedari perbuatannya yang

\footnotetext{
${ }^{22}$ H. Rothlisberger, Tafsiran Alkitab 2 Samuel Perjanjian Lama (Jakarta: BPK Gunung Mulia, 1983), hlm. 98.

${ }^{23}$ Ibid.

${ }^{24}$ Rothlisberger, Tafsiran Alkitab 2 Samuel Perjanjian Lama, hlm. 99.
} 
tidak baik atau krisis yang ia hadapi. Dalam hal ini, Tuhan menggunakan Natan sebagai konselor kepada Daud untuk memberikan nasihat dan teguran dengan cara yang terbaik sebagai contoh tindakan yang baik dalam pelayanan kaunseling. ${ }^{25}$

\section{E. METODE KONSELING PEMULIHAN MENURUT 2 SAMUEL 12:1-14}

Ada beberapa hal penting yang berkaitan dengan metode konseling pemulihan yang dibagi dalam beberapa hal sebagai berikut:

\section{Berani Dan Yakin}

Ketika Natan datang kepadanya dia mengira bahwa Natan datang membawa berita berkat seperti dalam dalam 2 Samuel 7:8-16. Sudah pastilah bahwa Daud tidak mengira bahwa Natan datang untuk menegur dia, sehingga Daud menerima Natan dengan baik. Keberanian Natan memberitahukan keputusan Tuhan dengan harapan bahwa raja akan sadar tentang dosanya. Natan berani menegur Daud karena Dia tahu bahwa Allah menyertai Dia. Sekalipun Natan tahu bahwa Daud adalah seorang raja. Panggilan Tuhan menyertai Natan, sehingga Daud bisa menyadari kesalahannya ketika ditegur oleh Natan.

Bagi seorang konselor, hal yang sangat sukar dihadapi adalah berhadapan dengan seseorang yang berpengaruh dalam masyarakat atau seorang yang kaya. Dalam cerita ini, hal tersebut dihadapi oleh Natan, di mana kedudukan Natan sangat jauh berbanding Daud dalam banyak aspek. Melihat latar belakang Daud, dia merupakan seorang raja yang sangat disanjung dan bahkan dihormati, bahkan David L. Baker mengatakan bahwa bisa saja seorang raja membunuh nabi yang demikian berani (bnd. Sikap raja Persia terhadap tamu, Est. 4:11). ${ }^{26}$

Keberanian dan keyakinan Natan untuk menghadapi krisis yang dihadapi oleh raja Daud seharusnya menjadi suatu contoh bagi seseorang hamba Tuhan yang bertindak sebagai konselor untuk

\footnotetext{
${ }^{25}$ http://www.studialkitab.com/2010/03/daud-ditegur-natan-ketidaksadaranakan.html.

${ }^{26}$ David L. Baker, Mari Mengenal Perjanjian Lama (Jakarta: BPK Gunung Mulia, 2009), hlm. 66.
} 
membantu. Sayangnya, setangah hamba Tuhan yang sepatutnya bertindak dalam pelayanan konseling justru berkompromi dengan dosa yang menjadi krisis seseorang sehingga jalan untuk membantu peribadi tertentu tidak menemui jalan penyelesaian.

\section{Pendekatan Non Direktif Persuasif}

Contoh dari nabi Natan seharusnya menjadi tolak ukur bagi para konselor Kristen masa kini. Yesus sendiri pernah melakukan hal tersebut ketika membela seorang wanita yang dibawah oleh ahli taurat yang kedapatan berzinah dalam kitab injil Yohanes 8:1-11. Dalam sebuah konseling pendekatan sangatlah penting. Pendekatan yang baik akan sangat menolong jalannya konseling tersebut. Namun sebaliknya jika pendekatan yang dilakukan salah akan sangat jelas bahwa konselor akan sangat susah untuk memecahkan masalah konsili tersebut. Dan dalam bagian ini Nabi Natan sangat hebat dalam mendekati Daud. Itulah sebabnya Magdalena Tomatala mengatakan pendekatan konseling yang dilakukan oleh nabi Natan bersifat non-direktif. Pendekatan non-direktif persuasif ini menggunakan pola komunikasi analogis yang diarahkan untuk menyentuh "hati nurani" konseli. ${ }^{27}$

Non-Direktif adalah suatu metode perawatan psikis yang dilakukan dengan cara berdialog antara konselor dengan klien, agar tercapai gambaran yang serasi antara ideal self (diri klien yang ideal) dengan actual self (diri klien sesuai kenyataan yang sebenarnya). ${ }^{28}$ Pendekatan ini juga pernah dipakai oleh Tuhan Yesus sewaktu ketika Tuhan bersama-sama dengan Nikodemus dalam Yohanes pasal 3. Pendekatan ini juga lebih cocok digunakan kepada kaum intelektual, biasanya disebut dengan istilah Intelektual Non-direktif. Magdalena mengatakan perlu disimak bahwa pendekatan ini dilakukan dengan pola dialog dengan struktur logika yang diarahkan untuk pencerahan akal yang menurun terhadap kesadaran diri atau kondisi diri. ${ }^{29}$ Dengan menggunakan metode atau langkah tersebut konseli atau klien dapat

${ }^{27}$ Tomatala, Konselor KompetenPengantar Konseling Terapi Untuk Pemulihan, hlm. 28

${ }^{28}$ Diambil 28 November 2016 http://rwiewied.blogspot.co.id/2011/03/ pendekatan-konseling-non-direktif.html.

${ }^{29}$ Tomatala, Konselor Kompeten Pengantar Konseling Terapi Untuk Pemulihan, hlm. 111 . 
terbuka dan bisa melangkah lebih jauh demi mengalami pemulihan dari Tuhan.

\section{Komunikasi Kreatif Analogi}

Entah apa yang terjadi dengan Daud hingga ia kehilangan kepekaan terhadap dosa yang sanga keji. Namun Allah dengan penuh kasih, mengutus seorang nabi yang bijaksana untuk menegur Daud, yaitu Natan. Natan tidak datang dengan pernyataan-pernyataan hukuman dari Allah, tetapi datang dengan sebuah kisah. Kisah yang sederhana yang pasti menggugah orang-orang yang masih memiliki kepekaan dan hati nurani. Natan menggunakan beberapa paralel, antara kisah perumpamaannya dengan apa yang dilakukan oleh Daud, yaitu: "Kaya - miskin," "banyak domba - satu domba." Si kaya mempunyai banyak domba sedangkan di miskin hanya memiliki seekor domba betina yang dirawat seperti anaknya sendiri. Natan menunjukkan bahwa si miskin ini sangat sayang dengan domba yang mereka miliki bahkan turut makan dan minum dari apa yang diberikannya kepada anakanaknya, bahkan domba ini tidur di pangkuan tuannya. Relasi yang sangat dekat seperti orang tua dan anak. Namun ketika si orang kaya yang mempunyai banyak domba tersebut kedatangn tamu, ia merasa sayang mengambil salah satu dombanya yang banyak itu. Karena ia punya kuasa, ia mengambil paksa, domba si orang miskin dan menghidangkannya kepada tamunya. Si orang kaya melakukan ketidakadilan yang membuat orang-orang yang mendengar kisah tersebut menjadi marah dan terusik hati nuraninya. ${ }^{30}$

Hasil komunikasi Natan kepada Daud juga memberikan dampak yang besar bagi Daud. Jika dilihat lebih dalam, penyerahan diri Daud terjadi oleh karena keterbukaannya. Dalam berkomunikasi biasanya seseorang atau kelompok memiliki tujuan dan hasil dalam berkomunikasi. Jika diamati komunikasi yang dilakukan Natan dan Daud pasti ada hasilnya. Gambaran analogi yang digunakan Natan sangatlah membawa pengaruh besar bagi Daud dan menyadari kesalahannya 2 Samuel 12:1-14. Payne mengatakan perumpamaan yang disampaikan oleh nabi Natan menyatakan kecerdikannya dalam dua hal, yaitu, Natan bukan hanya mengajak Daud untuk menyalahkan

\footnotetext{
${ }^{30} \mathrm{http} / / / w w w . s t u d i a l k i t a b . c o m / 2010 / 03 /$ daud-ditegur-natan-ketidaksadaranakan.html.
} 
dirinya sendiri tanpa disadarinya, tetapi juga merupakan tuntutan kepada raja selaku kepala hakim. ${ }^{31}$

Natan memberikan sebuah gambaran analogi bahwa ada kasus di mana seseorang kaya merampas dan menindas seorang yang miskin. Analogi yang dipakai Natan membuat hati Daud sebagai konseli tersentuh. Sehingga Daud memberikan feedback atau umpan balik kepada Natan. Umpan balik ini merupakan reaksi spontan atau matang yang diperlihatkan komunikan. Suasana yang terjadi dalam proses komunikasi dapat dibaca melalui bentuk dan isi feedback. ${ }^{32} \mathrm{Hal}$ inilah yang membuat Daud menyadari bahwa dia telah jatuh dalam dosa dan menyadarinya.

Menurut Larry Crabb, orang yang dikonseling harus menyadari bahwa ia telah jatuh dari norma yang ada. Ia telah gagal mencapai sasaran. Ia adalah manusia yang berdosa. ${ }^{33} \mathrm{Hal}$ inilah yang dirasakan Daud ketika mendengarkan analogi dari Natan. Dalam pelayanan konseling dan mengharapkan Tuhan, apabila seseorang itu meluahkan masalahnya, maka perkara utama dan sangat penting diamalkan adalah "lebih banyak mendengar daripada berkata-kata." Dengan demikian kita mengizinkan Tuhan melalui Roh Kudus untuk memberikan hikmat kepada kita untuk menanggapi dan bertindak sesuai dengan pimpinanNya. Dalam cerita ini, Natan sangat bijak menggunakan daya pikirnya menggunakan suatu cerita dalam bentuk ilustrasi yang sangat berkaitan dengan masalah raja Daud. Dengan ilustrasi tersebut raja Daud disadarkan dari perbuatannya (ay. 1-6). ${ }^{34}$ Dalam pelayanan konseling, senjata ampuh yang harus disadari oleh seorang konselor adalah 'hikmat berkata-kata' dan memahami keadaan masalah yang dihadapi oleh pribadi yang terlibat. Kaidah Natan dalam memberikan ilustrasi adalah suatu pendekatan yang kreatif, di mana ia membuat suatu komunikasi untuk memujuk seseorang itu menyedari masalahnya atau krisis yang ia hadapi.

\footnotetext{
${ }^{31}$ Payne, Tafsiran Alkitab Masa Kini, hlm. 485.

${ }^{32}$ S. M. Siahaan, Komunikasi Pemahaman Dan Penerapannya (Jakarta: BPK Gunung Mulia, 1991), hlm. 12.

${ }^{33}$ Crabb, Prinsip Dasar Konseling Alkitabiah, hlm. 55.

${ }^{34}$ https://hikmatpembaharuan.wordpress.com/2012/05/26/konseling-beberapamodel-pendekatan/.
} 


\section{Menggunakan Wibawa Nama Tuhan Dan Firman}

Dalam ayat 7-12, Natan dengan penuh wibawa menggunakan urapan Tuhan menyatakan kesalahan Daud, seorang yang mempunyai reputasi yang tinggi. Natan dengan keberanian mengatakan segala seuatu yang akan ditimpakan Tuhan terhadap perbuatan Daud. Dengan demikian Daud menyadari kesalahannya karena nama Tuhan diutamakan sebagai suatu objek yang dapat menyelesaikan dan mempunyai kuasa atas segala tindakan manusia. Hamba Tuhan harus menguasai seluruh kisah dalam Alkitab sebagai alat bantu dalam memberikan pendekatan kepada suatu masalah dan dengan tegas dan berani nyatakan kesalahan untuk setiap perbuatan yang dilakukan.

Natan melakukan hal yang tepat dan berani. Apa yang dilakukannya adalah langkah yang tepat dan menghormati Tuhan. Kierkegaard mengatakan apa yang dilakukan oleh Natan adalah atas dasar melakukan kebenaran-kebenaran firman Tuhan dan ketaatannya kepada Allah. ${ }^{35}$ Konselor juga harus bijaksana dan sangat bersandar kepada pimpinan Roh Kudus untuk menyatakan hal-hal seperti pendekatan yang diambil oleh Natan untuk menghadapi seseorang dalam konteks manusia masa kini.

\section{F. PENUTUP}

Undang-undang Sistem Pendidikan Nasional no. 20 tahun 2003 pasal 3 menyatakan bahwa Pendidikan Nasional berfungsi mengembangkan kemampuan dan membentuk watak serta peradaban bangsa yang bermartabat dalam rangka mencerdaskan kehidupan bangsa, bertujuan untuk berkembangnya potensi peserta didik agar menjadi manusia yang beriman dan patuh kepada Tuhan Yang Mahaesa, berakhlak mulia, sehat, berilmu, cakap, kreatif, mandiri, dan menjadi warga negara yang baik yang demokratis serta bertanggung jawab. ${ }^{36}$ Persoalan sekolah-sekolah bahkan kampus-kampus masa kini

${ }^{35}$ Yakub B. Susabda, Pastoral Konseling (Malang: Penerbit Gandum Mas, 2011), hlm. 2:210.

${ }^{36}$ Panduan Khusus Bimbingan Konseling Pelayanan Arah Peminatan Peserta Didik Pada Satuan Pendidikan Dasar Dan Menengah Asosiasi Bimbingan Dan Konseling Indonesia (Jakarta: Abkin, 2013), hlm. i. 
telah menjadi sorotan yang paling penting bagi pemerintah saat ini. Persoalan kini telah menjadi suatu fenomena bagi bangsa ini. Terlebih khusus dalam dunia pendidikan. Bahkan perilaku-perilaku yang menyimpang dari mahasiswa sekarang ini sangat meresahkkan masyarakat, sebab apa yang dilakukan oleh para pelajar ini telah mengarah kepada tindakan pencurian, mabuk, dan tindakan asusila. Itulah sebabnya sebagai tenaga pendidik kita perlu memperhatikan halhal tersebut sebagai hal yang penting dan dapat memikirkan cara yang tepat untuk dapat menolong siswa yang bermasalah tersebut. Tenaga pendidik dapat bersinergi menjadikan konseling sebagai bentuk bimbingan yang mencapai pemahaman diri seorang siswa, seperti yang dikatakan oleh Miller (I. Djumhur dan Moh. Surya, 1975) mengartikan bimbingan sebagai proses bantuan terhadap individu (siswa) untuk mencapai pemahaman diri yang dibutuhkan untuk melakukan penyesuaian diri secara maksimal di sekolah, keluarga dan masyarakat.

Sebagai tenaga pendidik, tugas kita bukan hanya sebagai guru, dosen, yang memiliki tugas sebagai pengajar saja, tetapi kita harus memikirkan juga pelayanan bimbingan konseling bagi siswa. Tugas mengajar itu sebagai kewajiban bagi guru, dosen, tetapi jangan pernah kita lupa bahwa sebagai tenaga pendidik kita juga bisa bertindak sebagai konselor untuk dapat menolong siswa yang kita didik.

\section{DAFTAR PUSTAKA}

Alkitab. Jakarta: Lembaga Alkitab Indonesia, 2010.

Baker, David L. Mari Mengenal Perjanjian Lama. Jakarta: BPK Gunung Mulia, 2009.

Collins, Gary R. Konseling Kristen Yang Efektif. Malang: Literatur SAAT, 2012.

Corey, Gerald. Teori Dan Praktek Konseling Dan Psikoterapi. Diterjemahkan oleh E. Koeswara. Bandung: PT. Eresco, 1988.

Crabb, Larry. Konseling Yang Efektif Dan Alkitabiah. Yogyakarta: Andi Offset, 2005. 
Diambil 3 November 2016. Konseling Yang Efektif \& Alkitabiah: Sebuah Acuan Untuk Membantu Anda Menjadi Konselor Yang Handa, PDF.

Diambil 5 November 2016.http://reformata.com/news/view/5390/ pemulihan-jiwa.

Diambil 7 November http://tholearies.blogspot.co.id/2014/02/bim bingan-konseling-pengertian-tujuan.html.

Diambil 28 November 2016 http://rwiewied.blogspot.co.id/ 2011/03/ pendekatan-konseling-non-direktif.html.

Hasugian, Johanes Waldes. "Kurikulum Dan Pembelajaran Warga Jemaat Dewasa Di Gereja." KURIOS (Jurnal Teologi dan Pendidikan Agama Kristen) 5, no. 1 (2019): 36-53.

Hasugian, Johanes Waldes. Menjadi Guru PAK Profesional Melalui Supervisi Pendidikan Agama Kristen. 2nd ed. Medan: CV. Mitra, 2016.

Hasugian, Johanes Waldes. Strategi Belajar Mengajar Pendidikan Agama Kristen Yang Efektif. Prodi Teologi STT-SU, 2016.

Heater, JR, Homer. Teologi Alkitabiah Perjanjian Lama. Diterjemahkan oleh Suhadi Yeremia. Malang: Gandum Mas, 2015.

Hommes, Tjaard G. dan E. Gerrit Singgih. Teologi Dan Praksis Pastoral. Antoloi Teologi Pastoral. Yogyakarta: Kanisius, 1992.

http://www.studialkitab.com/2010/03/daud-ditegur-natan-ketidak sadaran-akan.html.

Johnston, Philip. Pengantar Untuk Mengenal Alkitab Memahami Alkitab Berdasarkan Sejarah Tema Dan Penafsiran. Diterjemahkan oleh Christiaan Nugroho. Bandung: Yayasan Kalam Hidup, 2011.

Koeswara, E. Logoterapi: Psikoterapi Victor Frankl. Yogyakarta: Kanisius, 1992.

Panduan Khusus Bimbingan Konseling Pelayanan Arah Peminatan Peserta Didik Pada Satuan Pendidikan Dasar Dan Menengah Asosiasi Bimbingan Dan Konseling Indonesia. Jakarta: Abkin, 2013.

Payne, D. F. Tafsiran Alkitab Masa Kini. Jilid 1. Diterjemahkan oleh M. Rikin. Jakarta: Yayasan Komunikasi Bina Kasih, 2010. 
Prayitno, H. dan Erman Emti. Dasar-dasar Bimbingan Dan Konseling. Jakarta: Rhineka Cipta, 2013.

Rothlisberger, H. Tafsiran Alkitab 2 Samuel Perjanjian Lama. Jakarta: BPK Gunung Mulia, 1983.

Siahaan, S. M. Komunikasi Pemahaman Dan Penerapannya. Jakarta: BPK Gunung Mulia, 1991.

Susabda, Yakub B. Menjadi Konselor Yang Profesional. Yogyakarta: Andi Offset, 2007.

Susabda, Yakub B. Pastoral Konseling. Jilid. 2. Malang: Penerbit Gandum Mas, 2011.

Sutirna, H. Bimbingan Dan Konseling Pendidikan Forma Nonformal Dan Informal. Yogyakarta: Andi Offset, 2013.

Tomatala, Magdalena. Konselor Kompeten Pengantar Konseling Terapi Untuk Pemulihan. Jakarta: YT Leadership Foundation, 2000.

Zeni, Justice, and Zari Panggabean. "Pendekatan Praksis-Teologis Dalam Fondasi Pendidikan Kristiani." KURIOS (Jurnal Teologi dan Pendidikan Agama Kristen) 4, no. 2 (2018): 167-181. http://www.sttpb.ac.id/e-journal/index.php/kurios/article/view/81. 